\title{
CS-26 -Homologación de puestos en la red queso de poro genuino Balancán
}

\section{Homologation of positions in the net genuine pore cheese Balancán}

\author{
Raziel Esau Coop Abreu*, Yhadira Huicab Garcia, Kenia Landero Valenzuela
}

Instituto Tecnológico Superior de los Ríos, México

\author{
*Autor a quien se dirige la correspondencia: reca_dance@hotmail.com

\section{Resumen}

L os productos artesanales expresan la identidad mexicana, tanto en los modos de producción como en los hábitos de consumo; son parte de las tradiciones mexicanas; constituyen una herencia cultural única y viva. En la región de los Ríos del estado de Tabasco, se producen los mejores quesos del país; siendo el queso de poro el producto que es elaborado en el municipio de Balancán, Tabasco. Para permanecer en el mercado tan competitivo es importante que las pequeñas y medianas empresas (Pymes) utilicen estrategias que son cursos de acción que requieren de decisiones eficaces por parte de los propietarios para alcanzar sus objetivos y lograr el éxito de la empresa. La importancia del diseño de los perfiles y descripciones de puestos reside en la identificación de las aptitudes y habilidades deseables, además de la experiencia y conocimiento necesarios, para el desarrollo óptimo de las actividades de cada puesto dentro de la organización. Para garantizar el desempeño eficiente de los colaboradores, se hace necesario dar a conocer estas características deseables, y que sirvan como lineamientos en la selección de los colaboradores.

Palabras claves: Diseño, puestos, perfiles, descripción, homologación

\section{Abstract}

$\mathrm{H}$ andcrafted products express Mexican identity, both in modes of production and in consumption habits; they are part of the Mexican traditions; they are a unique and vivid cultural heritage. In the region of the rivers of the state of Tabasco, the best cheeses of the country are produced; being the cheese of pore the product that is elaborated in the commune of Balancan, Tabasco. To remain in the market so competitive it is important that SMEs use strategies that are courses of action that require effective decisions on the part of the owners to achieve their goals and achieve the success of the company. The importance of design of the profiles and descriptions of positions lies in the identification of desirable skills and skills, in addition to the necessary experience and knowledge, for the optimal development of the activities of each position within the organization. To guarantee the efficient performance of the collaborators, it is necessary to make known these desirable characteristics, and that they serve as guidelines in the selection of the collaborators.

Key words: Design, positions, profiles, description, homologation 